\title{
MENINGKATKAN AKTIVITAS DAN HASIL BELAJAR MATEMATIKA MENGGUNAKAN MODEL PEMBELAJARAN KOOPERATIF TIPE GROUP INVESTIGATION DI SMK TUMA'NINAH YASIN METRO
}

\author{
Irma Ayuwanti \\ Program studi Pendidikan Matematika, Universitas Nahdlatul Ulama Lampung \\ Email: cia_ituirma@yahoo.com
}

\begin{abstract}
Abstrak
Berdasar hasil Pra Survey yang dilaksanakan di SMK Tuma'ninah Yasin Metro diperoleh informasi bahwa siswa kurang aktif selama pembelajaran serta hasil belajar siswa masih relatif rendah. Sehingga dalam penelitian ini digunakan model pembelajaran kooperatif tipe Group Investigation (GI) dengan tujuan untuk mengetahui apakah dengan model pembelajaran kooperatif tipe Group Investigation (GI) dapat meningkatkan aktivitas dan hasil belajar siswa kelas X di SMK Tuma'ninah Yasin Metro semester genap tahun pelajaran 2015/2016. Jenis penelitian ini adalah Penelitian Tindakan Kelas (PTK). Jumlah siswa kelas $\mathrm{X}$ adalah 11 siswa. Teknik pengumpulan data melalui observasi dan tes. Instrumen dalam penelitian ini adalah tes tertulis berupa soal tes dalam bentuk uraian untuk mengukur hasil belajar siswa dan lembar observasi untuk mengukur aktivitas belajar siswa. Penelitian ini terdiri dari 3 siklus, setiap siklus meliputi perencanaan, pelaksanaan, observasi, dan refleksi. Aktivitas belajar siswa diamati dengan menggunakan lembar observasi. Hasil penelitian menunjukkan bahwa: 1) Pembelajaran menggunakan model pembelajaran kooperatif tipe Group Investigation (GI) dapat meningkatkan aktivitas belajar matematika siswa kelas X SMK Tuma'ninah Yasin Metro. 2) Pembelajaran menggunakan model pembelajaran kooperatif tipe Group Investigation (GI) dapat meningkatkan hasil belajar siswa dengan ratarata dari $27,5 \%$ siklus I menjadi 54,54\% pada siklus II dan menjadi $81,81 \%$ pada siklus III.
\end{abstract}

Kata Kunci: Aktivitas Belajar, Hasil Belajar, Group Investigation.

\section{Pendahuluan}

Pendidikan merupakan kegiatan terencana yang berlangsung sepanjang hidup dan menjadi kebutuhan bagi manusia. Pendidikan tidak hanya berlangsung di sekolah, akan tetapi dapat juga berlangsung di dalam keluarga dan masyarakat. Oleh karena itu, pendidikan menjadi tanggung jawab bersama antara keluarga, masyarakat, dan juga pemerintah. Pendidikan memegang peranan penting bagi kehidupan manusia. Tanpa pendidikan manusia akan sulit berkembang atau bahkan tidak berkembang. Dengan demikian, pendidikan harus benarbenar diarahkan agar menghasilkan manusia yang berkembang dan berkualitas serta mampu bersaing, di samping memiliki akhlak dan moral yang baik.

Keberhasilan belajar peserta didik dipengaruhi oleh beberapa faktor, dapat berasal dari diri peserta didik sendiri maupun dari guru sebagai pendidik. Faktor yang berasal dari guru di antaranya kemampuan dalam merancang pembelajaran yang mampu menumbuhkan motivasi belajar peserta didik, menciptakan suasana belajar yang menarik dan menyenangkan. Namun pada kenyataannya, peserta didik masih menganggap matematika sebagai mata pelajaran yang menakutkan sehingga susah untuk dipahami. Hal ini terjadi karena pendidik belum mampu mengemas pembelajaran matematika menjadi lebih menyenangkan yang mampu menarik perhatian peserta didik. Sehingga membuat prestasi belajar peserta didik tidak sesuai dengan yang diharapkan.

Proses pembelajaran saat ini masih cenderung menempatkan guru sebagai pusat pembelajaran atau satu-satunya sumber belajar. Guru hanya sekedar memberikan pengetahuan kepada siswa. Siswa tidak diberikan kesempatan untuk membangun sendiri pengetahuan yang dimilikinya. Tentunya keadaan seperti itu berpengaruh pada hasil belajar siswa. Untuk itu perlu adanya perubahan dalam proses pembelajaran dimana dalam proses 
pembelajaran lebih diarahkan pada keaktifan siswa. Guru dapat memberikan kesempatan kepada siswa untuk membangun sendiri pengetahuan mereka serta guru bukan satu-satunya sebagai sumber belajar. Oleh karena itu, guru diharapkan mampu memilih model pembelajaran yang sesuai dengan materi pembelajaran agar diperoleh hasil belajar siswa yang baik.

Matematika merupakan salah satu pelajaran yang harus diajarkan dalam sekolah, khususnya pada sekolah tingkat dasar, menengah, dan atas. Matematika pula menjadi salah satu pelajaran yang tidak disukai bagi kebanyakan siswa karena dianggap sulit. Dengan anggapan seperti itu membuat siswa enggan atau kurang bersemangat ketika pelajaran matematika. Sehingga berakibat pada hasil belajar matematika siswa yang kurang memuaskan atau masih tergolong rendah. Salah satunya di SMK Tuma'ninah Yasin Metro, aktivitas dan hasil belajar siswa pada mata pelajaran matematika masih tergolong rendah. Hal tersebut dapat dilihat pada tabel berikut:

Tabel 1. Data Aktivitas Belajar Siswa Kelas X SMK Tuma'ninah Yasin Metro

\begin{tabular}{rlcc}
\hline No & \multicolumn{1}{c}{ Aktivitas } & Frekuensi & $\%$ \\
\hline 1 & Diskusi materi & 2 & 18,18 \\
2 & Mengumpulkan informasi terkait dengan materi & 2 & 18,18 \\
3 & Bertanya terkait dengan materi & 4 & 36,36 \\
4 & Presentasi materi & 1 & 9,1 \\
5 & Kontribusi siswa dalam mengerjakan latihan & 2 & 18,18 \\
\hline
\end{tabular}

Tabel 2. Data Hasil Belajar Siswa Kelas Kelas X SMK Tuma'ninah Yasin Metro

\begin{tabular}{|c|c|c|c|}
\hline Nilai (KKM) & Kategori & Jumlah & $\%$ \\
\hline$\geq 70$ & Tercapai & 3 & 27,27 \\
\hline$<70$ & Belum Tercapai & 8 & 72,72 \\
\hline \multicolumn{2}{|c|}{ Jumlah } & 32 & 32 \\
\hline
\end{tabular}

Hasil penelitian Tran (2012), menyimpulkan pembelajaran kooperatif mengedepankan interaksi sosial, meningkatkan aktivitas, ingatan dan prestasi peserta didik. Penelitian Awofala, et. al (2012) menyimpulkan bahwa hasil post tes dengan pembelajaran kooperatif lebih baik daripada pembelajaran individual. Menurut Slavin (dalam Isjoni, 2010) bahwa "pembelajaran kooperatif adalah suatu model pembelajaran dimana sistem belajar dan bekerja dalam kelompok-kelompok kecil yang berjumlah 4-6 orang secara kolaboratif sehingga dapat merangsang lebih bergairah dalam belajar". Salah satu model pembelajaran kooperatif adalah Group Investigation (GI), GI adalah model pembelajaran kooperatif yang menuntut para peserta didik untuk memiliki kemampuan yang baik dalam berkomunikasi maupun dalam keterampilan proses kelompok (group process skills).

Dalam model pembelajaran kooperatif tipe GI guru mengidentifikasi topik dan membagi kelas dalam beberapa kelompok heterogen, merencanakan tugas yang akan dipelajari, melaksanakan investigasi, menyiapkan laporan akhir, mempresentasikan laporan akhir, dan evaluasi (Slavin, 2005). Berdasar hasil penelitian Tran (2012) tersebut untuk mengatasi permasalahan tersebut di atas, peneliti mengunakan model pembelajaran kooperatif tipe Group Investigation (GI) untuk meningkatkan aktivitas belajar siswa. Dengan menerapkan model pembelajaran kooperatif tipe Group Investigation (GI) diharapkan dapat meningkatkan aktivitas dan hasil belajar siswa. 


\section{Tinjauan Pustaka}

Belajar dalam pembelajaran kooperatif yang berpijak pada teori belajar konstruktivisme yaitu membangun pengetahuan sedikit demi sedikit yang kemudian hasilnya diperluas melalui konteks yang terbatas. Menurut teori belajar kontruktivisme, pengetahuan tidak dapat dipindahkan begitu saja dari pikiran guru ke pikiran peserta didik. Artinya bahwa peserta didik harus aktif secara mental membangun struktur pengetahuannya berdasarkan kematangan kognitif yang dimilikinya.

Menurut Anthony (dalam Trianto, 2010), "belajar sebagai proses menciptakan hubungan antara sesuatu (pengetahuan) yang sudah dipahami dan sesuatu (pengetahuan) yang baru". Menurut Hamalik (2008), "belajar adalah memodifikasi atau memperteguh kelakuan melalui pengalaman (learning is defined as the modification or strengthening of behaviour through experiencing)". Menurut Sardiman (2011), "belajar adalah suatu proses interaksi antara diri manusia (id-ego-super ego) dengan lingkungannya yang mungkin berwujud pribadi, fakta, konsep ataupun teori". Berdasarkan pengertian tersebut dapat diambil kesimpulan bahwa belajar adalah suatu proses interaksi yang dilakukan individu dengan lingkungannya untuk membangun pengetahuan baru berdasarkan pengetahuan yang sudah dimilikinya.

Belajar memerlukan aktivitas, seperti yang dikemukakan oleh Hamalik (2001) "pengajaran yang efektif adalah pengajaran yang menyediakan kesempatan belajar sendiri atau melakukan aktivitas sendiri”. Senada dengan hal tersebut, Winkel (dalam Riyanto, 2009) mengatakan "belajar adalah suatu aktivitas mental/psikis yang berlangsung dalam interaksi aktif dengan lingkungan, yang menghasilkan perubahan-perubahan dalam pengetahuanpemahaman, keterampilan, dan nilai sikap".

Berdasarkan pendapat para ahli, dapat ditarik kesimpulan bahwa aktivitas belajar adalah segala kegiatan belajar yang saling berinteraksi sehingga menimbulkan perubahan dari perilaku belajarnya, misalnya tidak tahu menjadi tahu, dari tidak mampu melakukan kegiatan jadi mampu melakukan kegiatan, dan lain sebagainya. Aktivitas siswa dalam kegiatan pembelajaran mempunyai peranan yang sangat penting dalam pembelajaran, tanpa aktivitas belajar itu tidak mungkin akan berlangsung dengan baik.

Hasil belajar merupakan sesuatu yang diperoleh siswa setelah mengikuti proses pembelajaran. Menurut Kunandar (2007) "hasil belajar adalah kemampuan siswa dalam memenuhi suatu tahapan pencapaian pengalaman belajar dalam satu kompetensi dasar". Menurut Abdurrahman (2003), "hasil belajar adalah kemampuan yang diperoleh anak setelah melalui kegiatan belajar".

Sedangkan menurut Romiszowski (dalam Abdurrahman, 2003) menyatakan bahwa: "Hasil belajar adalah keluaran (output) dari suatu sistem pemrosesan masukan (input). Masukan dari sistem tersebut berupa bermacam-macam informasi sedangkan keluarannya adalah perbuatan atau kinerja (performance)".

Menurut Bloom (dalam Suprijono, 2011) menyatakan bahwa:

Hasil belajar mencakup kemampuan kognitif, afektif, dan psikomotorik. Domain kognitif adalah knowledge (pengetahuan, ingatan), compherension (pemahaman, menjelaskan, meringkas, contoh), application (menerapkan), analysis (menguraikan, menentukan hubungan), synthesis (mengorganisasikan, merencanakan, membentuk, bangunan baru), dan evaluation (menilai). Domain afektif adalah receiving (menerima), responding (memberikan respon), valuing (nilai), organization (organisasi), characterization (karakteristik). Domain psikomotorik mencakup keterampilan produktif, teknik, fisik, sosial, manajerial, dan intelektual. 
Model pembelajaran kooperatif tipe GI sering dipandang sebagai model pembelajaran kooperatif yang paling kompleks dan paling sulit untuk dilaksanakan dalam pembelajaran. Model pembelajaran kooperatif tipe GI ini melibatkan peserta didik sejak perencanaan, baik dalam menentukan topik maupun cara untuk mempelajarinya melalui investigasi. Model pembelajaran ini menuntut para peserta didik untuk memiliki kemampuan yang baik dalam berkomunikasi maupun dalam keterampilan proses kelompok (group process skills).

Langkah-langkah Group Investigation menurut Sharan dan Sharan (1989), "Stage 1. Identifying the topic to be investigated and organizing students into research groups. Stage 2. Planning the investigation in groups. Stage 3. Carrying out the investigation. Stage 4. Preparing a final report. Stage 5. Presenting the final report. Stage 6. Evaluation”. (Tahap 1. Mengidentifikasi topik yang akan diselidiki dan pengorganisasian peserta didik ke dalam kelompok penelitian. Tahap 2. Merencanakan penyelidikan berkelompok-kelompok. Tahap 3. Melakukan investigasi. Tahap 4. Menyiapkan laporan akhir. Tahap 5. Menyajikan laporan akhir. Tahap 6.Evaluasi).

Langkah-langkah Group Investigation menurut Zingaro, et. al (2008):

First, the teacher presents a multi-faceted problem to the class, and students choose an interest group. Second, groups plan their investigation the procedures, tasks and goals consis- tent with the chosen subtopic. Third, groups carry out the investigation as planned in the above step. Fourth, groups plan their pre-sentation. They evaluate what they have learned, and synthesize it into a form that can be understood by the class. Fifth, groups conduct the pre- sentation. Finally, the teacher and students evaluate the investigation and resulting presentations. Throughout the process.

Langkah-langkah Group Investigation menurut Zingaro, et. al (2008):

1. Guru menyajikan masalah untuk kelas, dan peserta didik memilih minat kelompok.

2. Kelompok merencanakan investigasi mereka prosedur, tugas dan tujuan secara konsisten dengan subtopik yang dipilih.

3. Kelompok melakukan penyelidikan seperti yang direncanakan pada langkah tersebut.

4. Kelompok merencanakan presentasi. Mereka mengevaluasi apa yang telah mereka pelajari, dan mensintesis menjadi bentuk yang dapat dimengerti oleh kelas.

5. Kelompok melakukan presentasi. Akhirnya, guru dan peserta didik mengevaluasi penyelidikan dan presentasi.

Menurut Maesaroh (2005), model pembelajaran kooperatif Group Investigation (GI) memiliki beberapa kelebihan dan kelemahan yaitu sebagai berikut:

Kelebihan Group Investigation (GI) :

1. Pembelajaran berpusat pada peserta didik, sehingga peserta didik berperan aktif.

2. Pembelajaran yang dilakukan membuat suasana saling bekerjasama dan berinteraksi antar peserta didik dalam kelompok tanpa memandang latar belakang, setiap peserta didik dalam kelompok memadukan berbagai ide dan pendapat, saling berdiskusi dan beragumentasi dalam memahami suatu pokok bahasan serta memecahkan suatu permasalahan yang dihadapi kelompok.

3. Peserta didik dilatih untuk memiliki kemampuan yang baik dalam berkomunikasi.

4. Melatih peserta didik untuk menumbuhkan kemampuan berpikir mandiri.

5. Dapat membangkitkan semangat peserta didik untuk memiliki keberanian dalam mengemukakan pendapat dan berbagi informasi dengan teman lainnya dalam membahas materi pembelajaran.

Sedangkan kekurangan Group Investigation (GI) adalah sebagai berikut:

1. Banyak memakan waktu dalam proses pembelajaran.

2. Mahalnya sarana yang diperlukan. 
3. Saat berdiskusi, cenderung didominasi oleh seseorang, sehingga mengakibatkan peserta didik yang lain menjadi pasif.

Berdasarkan pendapat tersebut dapat disimpulkan bahwa langkah-langkah dalam model pembelajaran kooperatif tipe GI yang akan digunakan dalam penelitian ini adalah:

1. Pendahuluan

a. Guru menyampaikan tujuan pembelajaran dan memberikan motivasi.

b. Guru menjelaskan maksud pembelajaran dan tugas kelompok.

2. Inti

a. Guru menyampaikan informasi atau materi yang akan dipelajari.

b. Mengidentifikasi topik dan membagi kelas dalam beberapa kelompok heterogen.

c. Guru memanggil ketua membagi materi tugas yang berbeda.

d. Masing-masing kelompok secara kooperatif menginvestigasi tugas.

e. Membuat sintesis hasil investigasi kelompok.

f. Masing-masing kelompok menyampaikan hasil pembahasan kelompok.

g. Evaluasi (Setelah semua kelompok mempresentasikan hasil kerjanya, guru dan peserta didik berkolaborasi dalam membuat kesimpulan dan evaluasi pembelajaran peserta didik)

3. Penutup

a. Peserta didik dan guru merangkum isi pembelajaran.

b. Guru memberikan penghargaan kepada peserta didik untuk pembelajaran yang telah dilakukan.

c. Guru menginformasikan materi yang akan dibahas pada pertemuan selanjutnya.

\section{Metodologi Penelitian}

Penelitian ini dilakukan pada siswa kelas Kelas X SMK Tuma'ninah Yasin Metro dengan jumlah 11 siswa. Penelitian ini dilakukan 3 siklus yang masing-masing siklus terdiri dari perencanaan, pelaksanaan, pengamatan dan refleksi. Setiap siklus terdiri dari 3 kali pertemuan dengan 2 kali proses pembelajaran dan 1 kali tes akhir silkus. Setiap pertemuan 2 x 45 menit. Dalam penelitian ini, kegiatan yang akan dilakukan adalah mengamati aktivitas atau perilaku siswa dalam proses pembelajaran dan menilai hasil belajar siswa yang diukur dengan nilai tes. Tes dilakukan setiap akhir siklus dan observasi dilakukan dengan memberi tanda checklist pada aspek yang diobservasi dalam lembar observasi.

Instrumen yang digunakan dalam penelitian ini adalah sebagai berikut.

1. Validasi, yaitu suatu ukuran yang menunjukkan tingkat-tingkat kevalidan atau kesahihan sesuatu instrumen. Suatu instrumen yang valid atau sahih mempunyai validitas tinggi. Sebuah instrumen dikatakan valid apabila mampu mengukur apa yang diinginkan. Validator dalam penelitian ini adalah ibu Juitaning Mustika, S.Pd., M. Pd.

2. Reliabilitas: reliabilitas menyatakan sampai dimana keajegan ketepatan dari hasil pengukuran. Suatu tes dapat dikatakan mempunyai taraf kepercayaan yang tinggi jika tes tersebut dapat memberikan hasil yang tetap.

3. Indeks kesukaran item: butir-butir item tes hasil belajar dapat dinyatakan sebagai butirbutir item yang baik, apabila butir-butir item tersebut tidak terlalu sukar dan tidak pula terlalu mudah.

4. Daya pembeda item: daya pembeda item adalah kemampuan suatu butir item tes hasil belajar untuk dapat membedakan (mendiskriminasi) antara testee yang berkemampuan tinggi, dengan testee yang berkemampuan rendah demikian rupa sehingga sebagian besar testee yang memiliki kemampuan tinggi untuk menjawab butir item tersebut lebih banyak yang menjawab betul, sementara testee yang kemampuannya rendah untuk menjawab butir item tersebut sebagian besar tidak dapat menjawab item dengan benar. 


\section{Hasil dan Pembahasan}

Pembelajaran siklus I dilaksanakan sebanyak 3 pertemuan, masing-masing pembelajaran dilaksanakan selama 2 jam pelajaran ( 2 x 45 menit). Berikut hasil pengamatan atau observasi aktivitas siswa pada siklus I.

Tabel 3. Rata-rata Hasil Observasi Aktivitas Siklus I

\begin{tabular}{|c|c|c|c|c|c|c|}
\hline \multirow{2}{*}{ No } & \multirow{2}{*}{ Aktivitas yang diamati } & \multirow{2}{*}{$\begin{array}{c}\text { Target } \\
\text { PTK }\end{array}$} & \multicolumn{2}{|c|}{ Siklus I/Pertemuan } & \multirow{2}{*}{ Rata-rata } & \multirow{2}{*}{ Ket } \\
\hline & & & 1 & 2 & & \\
\hline 1 & $\begin{array}{l}\text { Membaca lembar kerja } \\
\text { siswa (LKS) }\end{array}$ & $\geq 90 \%$ & $92,55 \%$ & $96,77 \%$ & $94,66 \%$ & + \\
\hline 2 & $\begin{array}{l}\text { Menemukan masalah, } \\
\text { mencakup aktivitas } \\
\text { membaca petunjuk dan } \\
\text { tugas yang ada di dalam } \\
\text { lembar kerja siswa (LKS) }\end{array}$ & $\geq 90 \%$ & $83,87 \%$ & $90,32 \%$ & $87,10 \%$ & - \\
\hline \multirow{4}{*}{3} & $\begin{array}{l}\text { Menyelesaikan masalah: } \\
\text { a. Diskusi materi } \\
\text { kelompok }\end{array}$ & $\geq 60 \%$ & $83,87 \%$ & $87,10 \%$ & $85,49 \%$ & + \\
\hline & $\begin{array}{l}\text { b. Presentasi materi } \\
\text { antarkelompok }\end{array}$ & $\geq 60 \%$ & $74,19 \%$ & $61,29 \%$ & $67,74 \%$ & + \\
\hline & c. Mencatat hasil diskusi & $\geq 90 \%$ & $38,71 \%$ & $61,29 \%$ & $50 \%$ & - \\
\hline & $\begin{array}{l}\text { d. Menyimpulkan materi } \\
\text { antarkelompok }\end{array}$ & $\geq 50 \%$ & $70,97 \%$ & $51,61 \%$ & $61,29 \%$ & + \\
\hline
\end{tabular}

Keterangan:

$+=$ memenuhi target PTK

- = belum memenuhi target PTK

Tabel 4. Data Hasil Belajar Siklus I

\begin{tabular}{ccccc}
\hline \multirow{2}{*}{ No } & \multirow{2}{*}{ Nilai KKM } & \multirow{2}{*}{ Target PTK } & \multicolumn{2}{c}{ Penelitian Siklus I } \\
\cline { 4 - 5 } & & & Jumlah & Persentase \\
\hline 1 & $\geq 75$ & $75 \%$ & 3 & $27,5 \%$ \\
2 & $<75$ & $25 \%$ & 8 & $72,7 \%$ \\
\hline
\end{tabular}

Pembelajaran siklus II dilaksanakan sebanyak 3 pertemuan, masing-masing pembelajaran dilaksanakan selama 2 jam pelajaran ( 2 x 45 menit).

Berikut adalah hasil pengamatan yang dilakukan oleh observer pada siklus II:

Tabel 5. Rata-rata Hasil Observasi Aktivitas Siklus II

\begin{tabular}{|c|c|c|c|c|c|c|}
\hline \multirow{2}{*}{ No } & \multirow{2}{*}{ Aktivitas yang diamati } & \multirow{2}{*}{$\begin{array}{l}\text { Target } \\
\text { PTK }\end{array}$} & \multicolumn{2}{|c|}{ Siklus II/Pertemuan } & \multirow{2}{*}{ Rata-rata } & \multirow{2}{*}{$\mathrm{Ket}$} \\
\hline & & & 1 & 2 & & \\
\hline 1 & Membaca lembar kerja siswa (LKS) & $\geq 90 \%$ & $96,77 \%$ & $100 \%$ & $98,39 \%$ & + \\
\hline 2 & $\begin{array}{l}\text { Menemukan masalah, mencakup } \\
\text { aktivitas membaca petunjuk dan } \\
\text { tugas yang ada di dalam lembar } \\
\text { kerja siswa (LKS) }\end{array}$ & $\geq 90 \%$ & $90,32 \%$ & $96,77 \%$ & $93,55 \%$ & + \\
\hline \multirow[t]{2}{*}{3} & $\begin{array}{l}\text { Menyelesaikan masalah: } \\
\text { a. Diskusi materi kelompok } \\
\text { b. Presentasi materi } \\
\text { antarkelompok }\end{array}$ & $\begin{array}{l}\geq 60 \% \\
\geq 60 \%\end{array}$ & $\begin{array}{l}87,10 \% \\
83,87 \%\end{array}$ & $\begin{array}{l}90,32 \% \\
90,32 \%\end{array}$ & $\begin{array}{l}88,71 \% \\
83,10 \%\end{array}$ & $\begin{array}{l}+ \\
+\end{array}$ \\
\hline & $\begin{array}{l}\text { c. Mencatat hasil diskusi } \\
\text { d. Menyimpulkan materi } \\
\text { antarkelompok }\end{array}$ & $\begin{array}{l}\geq 90 \% \\
\geq 50 \%\end{array}$ & $\begin{array}{l}74,19 \% \\
74,19 \%\end{array}$ & $\begin{array}{l}77,42 \% \\
90,32 \%\end{array}$ & $\begin{array}{l}75,81 \% \\
82,26 \%\end{array}$ & $\begin{array}{l}- \\
+\end{array}$ \\
\hline
\end{tabular}


Keterangan:

$+=$ memenuhi target PTK

- = belum memenuhi target PTK

Tabel 6. Data Hasil Belajar Siklus II

\begin{tabular}{ccccc}
\hline \multirow{2}{*}{ No } & \multirow{2}{*}{ Nilai KKM } & \multirow{2}{*}{ Target PTK } & \multicolumn{2}{c}{ Penelitian Siklus II } \\
\cline { 3 - 5 } & & & Jumlah & Persentase \\
\hline 1 & $\geq 75$ & $75 \%$ & 6 & $54,54 \%$ \\
\hline 2 & $<75$ & $25 \%$ & 5 & $45,45 \%$
\end{tabular}

Pembelajaran siklus III dilaksanakan sebanyak 3 pertemuan, masing-masing pembelajaran dilaksanakan selama 2 jam pelajaran ( 2 x 45 menit). Berikut adalah hasil pengamatan yang dilakukan oleh observer pada siklus III:

Tabel 7. Rata-rata Hasil Observasi Aktivitas Siklus III

\begin{tabular}{|c|c|c|c|c|c|c|}
\hline \multirow{2}{*}{ No } & \multirow{2}{*}{ Aktivitas yang diamati } & \multirow{2}{*}{$\begin{array}{l}\text { Target } \\
\text { PTK }\end{array}$} & \multicolumn{2}{|c|}{ Siklus III/Pertemuan } & \multirow{2}{*}{ Rata-rata } & \multirow{2}{*}{ Ket } \\
\hline & & & 1 & 2 & & \\
\hline 1 & Membaca lembar kerja siswa (LKS) & $\geq 90 \%$ & $100 \%$ & $100 \%$ & $100 \%$ & + \\
\hline 2 & $\begin{array}{l}\text { Menemukan masalah, mencakup } \\
\text { aktivitas membaca petunjuk dan } \\
\text { tugas yang ada di dalam lembar } \\
\text { kerja siswa (LKS) }\end{array}$ & $\geq 90 \%$ & $100 \%$ & $100 \%$ & $100 \%$ & + \\
\hline \multirow[t]{5}{*}{3} & Menyelesaikan masalah: & & & & & \\
\hline & a. Diskusi materi kelompok & $\geq 60 \%$ & $83,87 \%$ & $93,55 \%$ & $88,71 \%$ & + \\
\hline & $\begin{array}{l}\text { b. Presentasi materi } \\
\text { antarkelompok }\end{array}$ & $\geq 60 \%$ & $87,10 \%$ & $83,87 \%$ & $85,48 \%$ & + \\
\hline & c. Mencatat hasil diskusi & $\geq 90 \%$ & $77,42 \%$ & $83,87 \%$ & $80,65 \%$ & + \\
\hline & $\begin{array}{l}\text { d. Menyimpulkan materi } \\
\text { antarkelompok }\end{array}$ & $\geq 50 \%$ & $67,74 \%$ & $74,19 \%$ & $70,97 \%$ & + \\
\hline
\end{tabular}

Keterangan:

$+=$ memenuhi target PTK

- = belum memenuhi target PTK

Tabel 8. Data Hasil Belajar Siklus III

\begin{tabular}{ccccc}
\hline \multirow{2}{*}{ No } & \multirow{2}{*}{ Nilai KKM } & \multirow{2}{*}{ Target PTK } & \multicolumn{2}{c}{ Penelitian Siklus III } \\
\cline { 3 - 5 } & & & Jumlah & Persentase \\
\hline 1 & $\geq 75$ & $75 \%$ & 9 & $81,81 \%$ \\
2 & $<75$ & $25 \%$ & 2 & $18,18 \%$ \\
\hline
\end{tabular}

Pengamatan atau observasi aktivitas belajar siswa mengalami peningkatan dari siklus I sampai siklus III. Hal tersebut dapat dilihat dari rata-rata setiap aktivitas yang diamati, yaitu pada aktivitas membaca lembar kerja siswa (LKS) dari rata-rata siklus I sebesar 94,66\%, rata-rata pada siklus II sebesar $98,39 \%$ dan rata-rata pada siklus III sebesar $100 \%$. Hal ini didukung dengan hasil penelitian Ningsih (2011) bahwa "untuk aktivitas membaca, rata-rata aktivitas siswa meningkat dari siklus I hingga siklus II".

Pada aktivitas yang kedua yaitu aktivitas menemukan masalah, mencakup aktivitas membaca petunjuk dan tugas yang ada di dalam membaca lembar kerja siswa (LKS), pada siklus I diperoleh rata-rata sebesar $87,10 \%$, pada siklus II diperoleh rata-rata sebesar 93,55\% dan pada siklus III diperoleh rata-rata sebesar $100 \%$. 
Aktivitas yang ketiga yaitu aktivitas diskusi materi kelompok, pada siklus I diperoleh ratarata $85,49 \%$, pada siklus II diperoleh rata-rata $88,71 \%$ dan pada siklus III diperoleh rata-rata sebesar 88,71\%. Hal ini didukung dengan hasil penelitian Fatimah (2010) bahwa "untuk aktivitas berdiskusi, rata-rata aktivitas siswa meningkat dari siklus I hingga siklus II".

Aktivitas yang keempat yaitu aktivitas presentasi materi antar kelompok, pada siklus I diperoleh rata-rata $67,74 \%$, pada siklus II diperoleh rata-rata sebesar $83,10 \%$ dan pada siklus III diperoleh rata-rata sebesar $85,48 \%$. Aktivitas yang kelima yaitu aktivitas mencatat materi, pada siklus I diperoleh rata-rata 50\%, pada siklus II diperoleh rata-rata $75,81 \%$ dan pada siklus III diperoleh rata-rata sebesar $80,65 \%$. Aktivitas keenam yaitu aktivitas menyimpulkan masalah antarkelompok memperoleh rata-rata $61,29 \%$ pada siklus I, rata-rata aktivitas pada siklus II diperoleh $82,26 \%$ dan diperoleh rata-rata sebesar 70,97\% pada siklus III.

Peningkatan hasil belajar siswa dalam penelitian yang telah dilakukan telah memenuhi target dalam penelitian ini. Pada penelitian ini KKM sebesar $\geq 75$, siklus I terdapat 27,5\% tercapai dan $72,7 \%$ yang belum tercapai. Pada siklus II terdapat 54,54\% tercapai dan $45,45 \%$ belum tercapai dan pada siklus III terdapat $81,81 \%$ tercapai dan $18,18 \%$ belum tercapai. Jadi tingkat ketuntasan dari siklus I ke siklus II terjadi peningkatan sebesar 27,04\% dan tingkat ketuntasan dari siklus II ke siklus III terjadi peningkatan sebesar 27,27\%.

Untuk ketuntasan belajar siswa pada akhir siklus telah melebihi target yang telah ditentukan yaitu 75\%. Hal ini didukung dengan hasil penelitian Fatimah (2010) bahwa "untuk tingkat ketuntasan siswa meningkat dari siklus I ke siklus II, hal ini karena siswa melakukan aktivitas-aktivitas saat pembelajaran berlangsung".

Suatu pembelajaran itu harus dapat mendukung siswa untuk melakukan aktivitas. Karena aktivitas dapat mempengaruhi hasil belajar, seperti yang dikemukakan Winkel (dalam Riyanto, 2009) menyatakan bahwa "belajar adalah suatu aktivitas mental/psikis yang berlangsung dalam interaksi aktif dengan lingkungan, yang menghasilkan perubahanperubahan dalam pengetahuan, pemahaman, dan nilai sikap".

\section{Simpulan dan Saran \\ Simpulan}

Berdasarkan hasil penelitian dan pembahasan yang telah dikemukakan maka dapat diambil kesimpulan sebagai berikut:

1. Pembelajaran dengan menggunakan Cooperative Learning model Group Investigationdapat meningkatkan aktivitas belajar matematika siswa kelas X SMK Tuma'ninah Yasin Metro.

2. Pembelajaran dengan menggunakan Cooperative Learning model Group Investigation dapat meningkatkan hasil belajar matematika siswa kelas X SMK Tuma'ninah Yasin Metro semester genap Tahun Pelajaran 2015/2016. Hal ini dapat dilihat dari rata-rata hasil belajar siswa yang meningkat dari $27,5 \%$ pada siklus I menjadi $54,54 \%$ pada siklus II, dan dari 54,54\% pada siklus II menjadi $81,81 \%$ pada siklus III. Bagi guru bidang studi matematika kiranya dapat menerapkan model pembelajaran kooperatif model tipe Group Investigation (GI) dalam pembelajaran sebagai salah cara untuk meningkatkan aktivitas dan hasil belajar siswa.

\section{Saran}

Saran yang dapat peneliti sampaikan berdasar pada penelitian yang dilakukan adalah:

1. Satu alternatif model pembelajaran untuk meningkatkan aktivitas dan hasil belajar siswa. Untuk menerapkan model pembelajaran kooperatif tipe Group Investigation (GI), guru harus memperhatikan hal-hal berikut: 
a. Guru harus lebih sering memberikan pengarahan dan bimbingan agar siswa tidak takut dan punya rasa percaya diri dalam bertanya dan lebih bersemangat dalam mengikuti pembelajaran.

b. Guru harus lebih tegas dalam mengkondisikan kelas agar siswa lebih aktif dan tidak bermalas-malasan dalam mengikuti proses pembelajaran.

c. Guru harus bisa memotivasi siswa agar memiliki keberanian untuk mempresentasikan atau menyampaikan materi di depan kelas.

d. Guru harus selalu memantau aktivitas kerja setiap kelompok agar diskusi kelompok berjalan dengan lancar.

2. Bagi siswa yaitu kiranya dapat terus melatih diri terlibat aktif dalam pembelajaran dengan model pembelajaran kooperatif model tipe Group Investigation(GI) khususnya dalam belajar matematika.

\section{Daftar Pustaka}

Abdurrahman, Mulyono. (2003). Pendidikan Bagi Anak Berkesulitan Belajar. Jakarta: PT Rineka Cipta.

Awofala, A. O. A., Fatade, A. O., and Ola-Oluwa, S. A.(2012). Achievement in Cooperative versus Individualistic Goal-Structured Junior Secondary School Mathematics Classrooms in Nigeria. International Journal of Mathematics Trends and Technology, Vol. 3 Tahun 2012. 7-12.

Fatimah, Dwi. (2010). Upaya Meningkatkan Aktivitas dan Hasil Belajar Matematika Melalui Pembelajaran Kooperatif Model Group Investigation Siswa Kelas XI SMA Negeri 2 Metro Tahun Pelajaran 2009/2010. Skripsi tidak diterbitkan. Metro: Program Sarjana Universitas Muhammadiyah Metro.

Hamalik, Oemar. (2001). Proses Belajar Mengajar. Jakarta: Bumi Aksara. (2008). Perencanaan Pengajaran Berdasarkan Pendekatan Sistem. Jakarta: Bumi Aksara

Isjoni. (2010). Cooperative Learning Efektivitas Pembelajaran Kelompok. Bandung: Alfabeta.

Kunandar. (2007). Guru Profesional Implementasi Kurikulum Tingkat Satuan Pendidikan (KTSP) dan Sukses dalam Sertifikasi Guru. Jakarta: PT RajaGrafindo Persada.

Maesaroh, S. (2005). Efektivitas Penerapan Pembelajaran Kooperatif dengan Metode Group Investigation terhadap Hasil Belajar Matematika Siswa. http: //gurupkn.wordpress.com/ 2010/03/23/.

Ningsih, E. R. (2011). Upaya Meningkatkan Aktivitas dan Hasil Belajar Matematika Menggunakan Metode Pembelajaran Kooperatif Tipe Group Investigation di SMK Negeri 1 Metro Tahun Pelajaran 2010/2011. Skripsi tidak diterbitkan. Metro: Program Sarjana Universitas Muhammadiyah Metro.

Riyanto, Yatim. (2009). Paradigma Baru Pembelajaran: sebagai Referensi bagi Pendidik dalam Implementasi Pembelajaran yang Efektif dan Berkualitas. Jakarta: Prenada Media Group.

Sardiman, A. M. (2011). Interaksi dan Motivasi Belajar Mengajar. Jakarta: PT Raja Grafindo Persada.

Sharan, Y. and Sharan, S. (1989). Group Investigation Expand Cooperative Learning. Educational Leadership, Vol. 47 No. 4 Tahun 1989. 17-21.

Slavin, R. E. (2005). Cooperative Learning: Teori Riset dan Praktik. Bandung: Nusa Media. 
Suprijono, Agus. (2011). Cooperative Learning (Teori dan Aplikasi PAIKEM). Yogyakarta: Pustaka Pelajar.

Tran, V. D. (2012). Effect of Cooperative Learning on Students at an Giang University in Vietnam. International Educational Studies, Vol. 5 No. 1 Tahun 2012. 86-99.

Trianto. (2010). Mendesain Model Pembelajaran Inovatif-Progresif. Jakarta: Kencana.

Zingaro, D. (2008). Group Investigation: Theory and Practice. Ontario Institute for Studies in Edocational. Toronto: Ontario. 